\title{
FOREIGN EXPERIENCE OF TRAINING FUTURE FOREIGN LANGUAGE TEACHERS USING INTERACTIVE TECHNOLOGIES
}

\section{ЗАРУБІЖНИЙ ДОСВІД ПІДГОТОВКИ МАЙБУТНІХ УЧИТЕЛІВ ІНОЗЕМНИХ МОВ ІЗ ВИКОРИСТАННЯМ ІНТЕРАКТИВНИХ ТЕХНОЛОГІЙ}

Serdiuchenko Yu.O.,

Postgraduate Student at the Department of English Philology

Zaporizhzhia National University
The article highlights some aspects of training future foreign language teachers and the formation of their foreign language communicative competence using interactive technologies in higher educational institutions around the world, including Germany, Finland, Norway, Great Britain, the United States of America, China and East Korea. The modern concept of continuing pedagogical education, which consists of three steps, is covered. The main attention is focused on primary pedagogical education, which future foreign language teachers obtain in universities. At the same time, the article lists the names of universities in Europe (Poland, Czech Republic, Spain, etc.), as well as in the United States of America, Canada and Australia, and areas of specialization offered at the philological and pedagogical faculties of these universities. It is emphasized that the leading universities in the above countries pay special attention to the use of interactive technologies in the educational process while training future foreign language teachers, and mastering pedagogical disciplines is mandatory. It has been found that foreign higher pedagogical institutions use such interactive methods as "meeting groups" (Germany) [4], "buzzing group", "group therapy", "effective teaching methods" (United States of America) [9], as well as role-playing games, discussions, trainings, etc. The article states that pedagogical practice is also considered by foreign universities as one of the important factors in the professional development of future foreign language teachers. During pedagogical practice, future teachers have the opportunity to apply the acquired knowledge in practice, and an interactivity in a new for them form takes place: "student - pupil", "student - mini-group of pupils", "student - group of pupils".

Key words: interactive learning technologies, foreign language communicative competence, interactivity, educational process, foreign experience.

комунікативної компетентності із використанням інтерактивних технологій $y$ вищих навчальних закладах різних країн світу, зокрема у Німеччині, Фінляндії, Норвегії, Великій Британії, Сполучених Штатах Америки, Китаї та східній Кореї. Висвітлюється сучасна концепція безперервної педагогічної освіти, яка складається 3 трьох кроків. Основна увага зосереджується саме на первинній педагогічній освіті, яку здобувають майбутні учителі іноземної мови в iнститутах та університетах. Водночас у cmaтmі приведено перелік назв університетів у країнах Європи (Польща, Чехія, Іспанія тощо), а також у Сполучених Штатах Америки, Канаді та Австралії, та напрями спеціалізацій, які пропонуються на фрілологічних та педагогічних ффакультетах у зазначених університетах. Підкреслено, що провідні університети у вищезазначених країнах приділяють особливу увагу застосуванню інтерактивних технологій в освітньому процесі під час підготовки майбут ніх учителів іноземної мови, а опанування педагогічними дисциплінами є обов'язковим. З'ясовано, що у зарубіжних педагогічних закладах вищої освіти застосовуються такі інтерактивні методи, як «групи зустрічей» (Німеччина) [4], «жужача група», «групова терапія», «методи ефрективного навчання» (Сполучені Штати Америки) [9], а також рольові ігри, дискусії, тренінги тощо. Наголошується, що проходження педагогічної практики також вбачається зарубіжними університетами одним із важливих чинників професійного становлення майбутніх учи телів іноземної мови. Під час педагогічної практики майбутні вчителі мають можливість застосовувати набуті знання на практиці, а також відбувається інтерактив у новій для них формі: «студент - учень», «студент - мінігрупа учнів», «студент група учнів».

Ключові слова: інтерактивні технологіі навчання, іншомовна комунікативна компетентність, інтерактив, освітній процес,

статті виокремлюються окремі аспек підготовки майбутніх учителів іноземної мови та фрормування їхньої іншомовноі зарубіжний досвід.
Problem statement in general. Currently, the main goal of training future foreign language teachers is the formation of their ability to perform oral and written intercultural communication, namely the formation of their foreign language communicative competence. We believe that the use of interactive technologies in the educational process while training future teachers of foreign languages will help achieve the aforementioned goal. In order to better understand the state of training of future foreign language teachers and objectively identify the gaps in the development of their communicative competence while using interactive technologies, we consider it appropriate to study foreign experience in this matter.
Analysis of recent research and publications. The analysis of recent studies has demonstrated that the issue of state and improvement of professional education of future teachers is of great significance (B. Jandhyala, G. Tilak). It should be noted that researchers pay particular attention to the issue of training future foreign language teachers (L. Orlova, M. Lane, O. Mashkina, Ye. Chalaya, I. Mayburov, K. Klemet). Such researchers as O. Pometun, L. Pyrozhenko, G. Selevko, S. Kashlev devoted their studies to the problems of interactive learning technologies. N. Sura, Yu. Solodovnikova, G. Ivanchuk, O. Chorna and others considered in their studies 
modern approaches to the formation of foreign langage communicative competence.

Highlighting previously unsolved issues of the common problem. Despite the fact that researchers pay a lot of attentions to the problems of training future teachers of foreign languages in higher educational institutions, the possibility of introducing foreign experience in this issue is still relevant. In particular, the implementation of foreign experience while developing foreign language communicative competence using interactive technologies is of great interest.

The purpose of this article is to outline foreign experience in the formation of foreign language communicative competence of future teachers of foreign languages in higher educational institutions using interactive learning technologies.

Main body. Today, the concept of lifelong teacher education consists of three steps: 1) teacher training college / high school / university, 2) adaptation period, 3) in-service education. Primary in-depth pedagogical education - step 1 - is provided by colleges, high school and universities. The adaptation period - step 2 - takes place under the supervision of more experienced teachers and lasts from one to three years. In-service teacher training - step 3 - is based on attending long-term or short-term courses in higher educational institutions, specialized institutions, teacher training centers and schools (the latter is more common in the UK and the USA).

In our study, we focus on the primary pedagogical education that future foreign language teachers obtain in universities, which, in its turn, allows for teaching in secondary schools.

World leading universities offer the training of teachers, including foreign language teachers, in specialized faculties with obligatory mastery of pedagogical disciplines. Among leading universities for training foreign language teachers in Europe are the following ones: Albert-Ludwigs Universitat Freiburg, Justus-Liebig-Universitat Gieben and Universitat Siegen (Germany); SWPS University of Social Sciences and Humanities, Jagiellonian University (Poland); English-American University (Anglo-American University), Charles University (Czech Republic); University Autonoma de Barcelona (Spain) and others. The above universities offer at the Faculty of Philology such specialties as English Philology, English and American Studies, Eastern Slavic Studies, Germanic Studies, Greek Philology, Danish philology, Spanish Language, Literature and Culture, Spanish, Italian Philology, Catalan Philology, Classical Philology, Latin Studies, Latin Philology, Interdisciplinary Study of French Philology, German Philology, German as a second language, Norwegian, Portuguese, Romance Philology, Russian Studies, Scandinavian, Slavic Studies, French Philology, Swedish. In the United Kingdom, Keele University and Liverpool John Moores University were recognized as the best ones in philological training, and in Ireland, University College Dublin - as the best one for mastering the specialty of the English language. There is a large number of higher educational institutions in the USA, including Foothill and DeAnza Colleges, King's Education New York, Louisiana State University, Manhattan College, New England College, Roosevelt University, University of Central Florida, University of Kansas, University of Maine, University of South of Carolina, University of Southern Maine, University of Vermont, where students can acquire the speciality in Chinese, English, French, German and Spanish. Such universities as the University of Calgary in Canada, the University of Sydney in Australia, Peking University in China also train foreign language teachers.

Modern trends in the development of foreign schools, which are characterized by a clearly defined transition from "subject-object" relationship between a teacher and a student to "subject-subject" and dialogic relations, which provide for the fullest possible selfrealization of each student's own potential and lead to the modernization of teacher training process [8].

The most remarkable universities which introduce the latest technologies and methods in education are the universities in Germany, Finland, Norway, Great Britain, the United States of America, China and East Korea.

The experience of foreign countries is usually considered starting with European countries, as the process of training in higher educational institutions for future professionals takes place in accordance with the Bologna Declaration (1999), the Council of Europe Recommendations (2002), the Education Tuning Project (2003) [1].

The teacher training program in Germany provides for the principle of interaction and, as I. Maiburov notes [4], includes three blocks. The first block is dedicated to educational activities and consists of modules for personal development, social foundations of problems in education, psychological and personal development in the process of self-knowledge and person-to-person interaction. Specialists in the field of communication help students with this. They arrange students' participation in groups of "meetings". Participation in groups of "meetings" is an interactive method, which contributes to the development of students' communicative skills based on such forms of interaction as "student-student", "student-group of students", "student-specialist", "group of students-specialist".

The second block is dedicated to a "meeting" with basic skills, the task of which is to teach students to associate the theory of learning with their experience of teaching in a group. Future foreign language teachers work with a group of 7-10 pupils three times a week. They are fully responsible for teaching pupils. Thus, a full immersion in interaction, which involves 
"student-student", "student-mini-group of students", "student-group of students" form of communication, takes place. Difficulties that arise during such classes are discussed in weekly classes of the group of "meetings". Such classes involve interactive methods and contribute to the development of communicative skills in monologue and dialogical speech in the form of "student-specialist".

The third block is aimed at immersing of a future foreign language teacher in the interactive activities and consists of two main modules, namely: "meeting" with the role of a teacher and "meeting with an experienced teacher". In the course of such "meetings", regular seminars are organized to discuss problems and invent possible solutions in the presence methodologists, leaders and specialists in pedagogical psychology.

Thus, the training of foreign language teachers in Germany tends to seminars with the possibility of free group discussions, which stimulate the independence and initiative of students in discussing problems. The most popular are interdisciplinary seminars, seminars led by students, micro-teaching - trainings - imitation of individual elements of the lesson, extracurricular work in the form of a group project.

Being a teacher in Finland is very prestigious. Language and literature teachers have particularly high status as teaching writing and reading is considered sacred to everyone in this country. This country has developed a structure of teacher training based on the systematic study of society and its development. Teacher training also includes direct contact, namely interaction in the form of a dialogue, discussion, etc., and in close contact with society. In addition to the traditional use of interactive methods with the purpose of development of communicative skills from the 1st to the 4th year of study, future foreign language teachers are offered a four-week teaching practice, and in the 5th year - a five-week one. In the course of teaching practice, future foreign language teachers come into direct contact with pupils in pilot schools at higher educational institutions to master the skills of identifying problems in schools, classrooms, evaluating, analyzing events and finding ways to solve them. The educational process for the training of a foreign language teacher has 180 credit hours in the bachelor's degree and 120 credit hours in the master's degree programme, which corresponds to a minimum of 52.5 ECTS [6].

In Norway, an important component of educational policy is to ensure the professional development and high level of skill of teachers who are able to creatively comprehend the pedagogical situation and design their own activities [3]. Based on this, in the course of training foreign language teachers, fragments of the "Drama" interactive technique are introduced, according to which future teachers of foreign languages create possible situations and find options for their solution.
In the UK, in the course of professional training of modern teachers, a great attention is paid to mastering various pedagogical techniques, specific skills of teaching and educational work, which are practised during traditional classes - in seminars, workshops, laboratory classes, and through the use of new forms and methods of teaching techniques: modeling, role-playing games, etc. [2], which contributes to the development of communicative competence of a future teacher of foreign languages.

In the educational system of the United States of America, a lot of time is devoted to the development of language teachers' communicative skills based on the idea of humanistic pedagogy. Special classes are dedicated to the culture of speech, voice- and articulation training. American future teachers, in particular future teachers of foreign languages, go through the course called "Means of communication" and special attention is paid to the pedagogical practice lasting 4-16 weeks [9], which contributes greatly to the development of communicative skills. Such methods as "group therapy", "buzzing group", "brainstorming", "aquarium", seminars with a focus on both an individual student and a small group are used to improve the educational process. In large groups, they introduce methods of discussion, survey, information review, etc. The most effective methods are considered to be "methods of effective learning", including role-playing games and tasks aimed at the development of imagination [9].

To obtain a profession of a foreign language teacher in China, it is necessary to graduate from the pedagogical faculty of the university or other similar faculties and gain knowledge in the disciplines of the pedagogical cycle of 30 ECTS [5].

The East Korean Ministry of Education claims that high-quality education is impossible without highquality teacher training. Future teachers, in particular future teachers of foreign languages, are trained at the relevant faculties (philology, humanities) with the obligatory mastering of 42 credits in the field of pedagogy at the master's level of education [7].

Conclusions. As a result of the study, it should be noted that the use of interactive technologies is an important aspect in the process of training future foreign language teachers in foreign higher educational institutions. The modern tendency in the development of pedagogical education abroad is characterized primarily by subject-subject, dialogue relationship between students and a teacher. Such form of relationship provides for the self-realization of each student's own potential. With this purpose, for the training of future foreign language teachers, foreign universities are introducing various methods of interactive technologies, which are also aimed at forming foreign language communicative competence of future professionals. At the same time, special pedagogical disciplines and 
programmes for teaching practice are being introduced. It should be noted that the awareness of the peculiarities of training future foreign language teachers in foreign universities will allow applying their best experience in the domestic educational process.

The development of recommendations for the domestic educational system related to the use of interactive technologies in the process of training future foreign language teachers is considered as the further area of our study.

\section{BIBLIOGRAPHY:}

1. Драч А.С. Формування читацької компетентності майбутніх учителів іноземної мови засобами навчальних комп'ютерних програм : дис. ... канд. пед. наук : 13.00.04 / Запорізький національний університет. Запоріжжя, 2019. 386 с.

2. Ірландський освітній портал. URL: www.scoilnet. іе (дата звернення: 10.02.2021).

3. Клемет К. На пути к "Knowledge Society". Alma mater: Вестник высшей школы. 2005. № 2. C. 132-144.
4. Майбуров И. Высшее образование в развитых странах. Высшее образование в России. 2003. № 2. C. $132-134$.

5. Машкина О.А. Формирование новой модели подготовки школьных учителей в современном Китае. Вестник Московского университета. Серия 20. Педагогическое образование. 2013. № 3. C. $108-122$.

6. ОрловаЛ.В.Современноепедагогическое образование в Финляндии и Швеции: структура и содержание. Вестник Северного (Арктического) фредерального университета. Серия: Гуманитарные и социальные науки. 2015. С. 149-156.

7. Чалая Е.В. Ценностные составляющие профессиональной педагогической подготовки учителей в Республике Корея. Вестник Томского государственного педагогического университета. Томск. 2014. № 4 (145). C. 143-147.

8. Jandhyala B., Tilak G. Global trends in the funding of higher education. IUA Horizons (World Higher Education News). 2005. Vol.11. P. 1-3.

9. Lane M. Clustering. Improving college and university teaching. P. 27-URL: www.ncate.org/standard/ programstds.htm (дата звернення: 10.02.2021). 